\title{
FAKTOR-FAKTOR YANG BERHUBUNGAN DENGAN KINERJA PERAWAT RUMAH SAKIT DI PROVINSI BANGKA BELITUNG TAHUN 2017
}

\author{
Dwi Fakhrulia ${ }^{1}$, Fajar Ariyanti ${ }^{2}$ \\ ${ }^{1,2}$ Program Studi Kesehatan Masyarakat, Fakultas Ilmu Kesehatan, Universitas Islam Negeri \\ (UIN) Syarif Hidayatullah Jakarta \\ Email:fajar.ariyanti@uinjkt.ac.id
}

\begin{abstract}
ABSTRAK
Performance is practical behavior as a work achievement that is produced by individuals according to their role in company. The performance of nurse is the ability of a nurse to perform nursing in accordance with their roles, functions, and responsibilities in accordance with organizational objectives. Performance can be influenced by individual characteristics and work motivation. The purpose of this study was to identify the factors that related to performance of nurse at hospital in Bangka Belitung Province in 2017. Design of this study was quantitative using a cross sectional approach. This study used secondary data from the research of health workers (Risnakes) in 2017. The data from Risnakes was analyzed from August to November 2020. The sample in this study amounted 197 nurses who worked at Hospital in Bangka Belitung Province. The statistical test used chi-square with CI 95\%. The results showed that there was association between work motivation $(p=0.020)$ with performance of nurse at hospital in Bangka Belitung Province. Meanwhile there was no association between individual characteristics (age, sex, education, marital status, working period) with performanceof nurse at hospital in Bangka Belitung Province. The conclusion of this study was work motivationcould affect performance of nurse at hospital in Bangka Belitung Province. Therefore the hospital leader should pay attention to improve work motivation which affect performance of nurse at hospitalin Bangka Belitung Province.
\end{abstract}

Keywords: work motivation; work performance; nurse; hospital; individual characteristics

\section{PENDAHULUAN}

Kinerja merupakan perilaku yang berwujud, yang seseorang tampilkan sebagai suatu prestasi kerja karyawan berdasarkan perannya di dalam perusahaan (Veizal, 2004). Menurut Suwondo dan Sutanto (2015), penilaian kinerja diukur dengan cara sebagai berikut: (1) Akurasi pekerjaan yang dilakukan yaitu ketepatan pekerjaan yang dilakukan, penekanan pada kualitaspekerjaan yang dilakukan, kemampuan mencapai tujuan perusahaan dan kemampuan menyelesaikan pekerjaan tepat waktu. (2)Tingkat inisiatif, meliputi kemampuan mengantisipasi kemungkinan masalah dan kemampuan suatu masalah, dan kemampuan alternatif pemecahan masalah tersebut. (3) ketangkasan berpikir dicapai melalui kemampuan karyawan untuk memahami arahan yang diberikan oleh pemimpin dan kemampuan karyawan untuk bekerja sama, kemampuan mengukur diri sendiri oleh rekan kerja lainnya. (4) Disiplin waktu dan kehadiran berarti ketepatan waktu

DOI : https://doi.org/10.51544/jmn.v4i2.1824

(C) 2021 Jurnal Mutiara Ners. This is an open accessarticleunder the CC BY-SA license Website : http://e-journal.sari-mutiara.ac.id/index.php/NERS/index 
dan tingkat kehadiran karyawan di tempat kerja.

Menurut Gibson (1996) berpendapat bahwa variabel yang dapat mempengaruhi perilaku dan kinerja yaitu variabel individu, variabel organisasi, dan psikologis. Motivasi kerja adalah jumlah upaya yang dilakukan seseorang untuk memenuhi tugasnya. Usia yang masih berkaitan dengan kemampuan dan keterampilan kerja seseorang, selain itu, usia juga dapat mempengaruhi kondisi fisik dan psikis seseorang, serta usia akan semakin tua seseorang sering mengalami perubahan potensi dan produktivitas kerja. usia produktiv dikatakan dimulai pada umur

20 sampai 35 tahun, karena pada umur tersebut memiliki idealisme tinggi dan energi yang luar biasa (Handoko, 1997). Pengalaman biasanya berkaitan denganwaktu mulai bekerja, dan pengalaman kerja juga menentukan kinerja seseorang. Semakin lama bekerja, maka telah beradaptasi dengan baik dengan pekerjaan, jadi keterampilannya akan lebih baik. Hasil proses interaksi jangka panjang dengan anggota keluarga mengkinkan mereka memperoleh pengalaman diantara anggota keluarga. Keterampilan fisik diperoleh melalui pendidikan formal dalam bentuk pendidikan kelembagaan atau informal dan dalam bentuk bimbingan kerja.

Menurut Shattuck et al (2008) hal yang berkaitan dengan faktor motivasi yaitu: Keuangan dapat berupa gaji atau tunjangan; Pengembangan karir dalam hal keahlian atau promosi; Pendidikan berkelanjutan; Infrastruktur rumah sakit, kondisi fisik ataupun lingkungan kerja; Ketersediaan sumber daya untuk melakukan pekerjaan mereka; Manajemen rumah sakit dimana hubungan dengan manajemen dan kolega baik; Pengakuan atau apresiasi pribadi baik dari manajer, serta kolega dari komunitas.

Pada data Risnakes tahun 2017, diketahui terdapat kategori motivasi rendah, sedang dan tinggi. Tidak terdapat motivasi rendah di seluruh provinsi di Indonesia. Namun pada kategori sedang, ditemukan Provinsi Bangka Belitung masuk kedalam provinsi dengan motivasi yang rendah sebesar 36,7 \%, sedangkan rata-rata motivasi indonesia tahun 2017 yaitu 53,2\%. Maka peneliti ingin melihat "Faktor-faktor yang berhubungan dengan kinerja perawat rumah sakit di Provinsi Bangka Belitung Tahun 2017 '.

\section{METODE PENELITIAN}

Penelitian ini merupakan studi analitik terhadap data sekunder dari Riset ketenagakerjaan di Bidang Kesehatan (RISNAKES) Tahun 2017. Desain penelitian yang digunakan adalah metode cross sectional (potong lintang). Analisis data RISNAKES dalam penelitian ini dilakukan pada bulan Agustus-November tahun 2020 Variabel independen, yaitu motivasi kerja dan karakteristik individu (umur, jenis kelamin, pendidikan, statusperkawinan, lama kerja) dan variabel dependen yaitu Kinerja perawat rumah sakit di Provinsi Bangka Belitung. Populasi penelitian ini adalah seluruh responden petugas rumah sakit di Provinsi Bangka Belitung yang terdiri dari 17 rumah sakit dengan jumlah populasi 510 orang. Sampel dalam penelitian ini adalah seluruh responden perawat berjumlah 197 responden. Uji statistik yang digunakan adalah uji Chi-Square, dan taraf signifikansi $\alpha=0,05$ (tingkat kepercayaan 95\%). Instrumen mengacu pada pengukuran Minnesota Satisfaction Questionnaire dengan pilihan jawaban dari skala 1-5 (sangat setuju hingga sangat tidak setuju).Penilaian kinerja perawat diukur melalui variabel dependen yang telah dikategorikan berdasarkan $25 \%$ instrumen tingkat inisiatif dan $75 \%$ instrumen kedisiplinan waktu. Data RISNAKES telah mendapatkan persetujuan 
Etik dari Komisi Etik Penelitian Kesehatan Badan Litbang Kesehatan (LB.02.01/2/KE.130/2017) dan Penelitian ini telah mendapatkan persetujuan etik dari Komisi Etik Fakultas Ilmu Kesehatan UIN Syarif Hidayatullah Jakarta. (Un.01/F.10/KP.01.1/KE.SP/012.08.001/20 20).

\section{HASIL}

1. Analisis Univariat

Berdasarkan tabel 1 menunjukkan bahwa dari 197 responden, sebanyak 92 orang perawat memiliki kinerja yang kurang $(46,7 \%)$, sedangkan perawat memiliki kinerja yang baik sebanyak 105 orang $(53,5 \%)$. Berdasarkan karakteristik umur menunjukkan bahwa dari 197 responden, sebanyak 75 orang perawat berumur $\leq 30$ tahun $(61,9 \%)$, sedangkan perawat berumur $\leq 30$ tahun sebanyak 122 orang $(61,9 \%)$. Berdasarkan karakteristik jenis kelamin menunjukkan bahwa dari 197 responden, sebanyak 148 responden $(75,1 \%)$ merupakan perempuan, kemudian 49 responden $(24,9 \%)$ merupakan laki-laki.

Berdasarkan karakteristik pendidikan menunjukkan bahwa dari 197 responden, sebanyak 149 responden $(75,6 \%)$ memiliki pendidikan D4/S1/S2, kemudian 48 responden $(24,4 \%)$ memiliki pendidikan D3. Berdasarkan karakteristik status perkawinan menunjukkan bahwa dari 197 responden, sebanyak 141 responden $(71,6 \%)$ sudah kawin, kemudian 56 responden $(28,4 \%)$ belum kawin. Berdasarkan karakteristik lama kerja menunjukkan bahwa dari 197 responden, sebanyak 155 responden $(78,7 \%)$ telah bekerja selama lebih dari 10 tahun, kemudian 42 responden $(21,3 \%)$ telah bekerja selama kurang dari 10 tahun. Berdasarkan motivasi kerja menunjukkan bahwa dari 197 responden, sebanyak 137 responden $\quad(69.5 \%)$ mempersepsikan motivasi yang diperoleh kategori kurang baik, kemudian 60 responden (30.5\%) mempersepsikan motivasi yang diperoleh kategori baik.

Tabel 1. Distribusi Kinerja, Karakteristik Individu, Motivasi Perawat Rumah Sakit Provinsi Bangka Belitung Tahun 2017

\begin{tabular}{lll}
\hline & n & \% \\
\hline Kinerja & & \\
Baik & 105 & 53.3 \\
Kurang Baik & 92 & 46.7 \\
Umur & & \\
$\geq 30$ tahun & 75 & 38.1 \\
< 30 tahun & 122 & 61.9 \\
Jenis Kelamin & & \\
Perempuan & 49 & 24.9 \\
Laki-laki & 148 & 75.1 \\
Pendidikan & & \\
D4/S1/S2 & 48 & 24.4 \\
D3 & 149 & 75.6 \\
Status Perkawinan & & \\
Sudah Kawin & 56 & 28.4 \\
Belum Kawin & 141 & 71.6 \\
Lama Kerja & & \\
$>10$ Tahun & 155 & 78.7 \\
<10 Tahun & 42 & 21.3 \\
Motivasi & & \\
Baik & 60 & 30.5 \\
Kurang & 137 & 69.5 \\
\hline Sumber: Data Diolah, 2020 & &
\end{tabular}

2. Analisis Bivariat

Berdasarkan tabel 2 hasil tabulasi silang umur dengan kinerja perawat rumah sakit Provinsi Bangka Belitung Tahun 2017 diperoleh bahwa dari 194 orang, yang memiliki umur $\geq 30$ tahun sebanyak 42 orang (40\%) yang memiliki kinerja baik, sebanyak 33 orang $(35,9 \%)$ yang memiliki kinerja kurang. Pada umur $\leq 30$ tahun sebanyak 63 orang $(60 \%)$ yang memiliki kinerja baik, sebanyak 59 orang $(64,1 \%)$ 
yang memiliki kinerja kurang. Berdasarkan uji Chi-Square menghasilkan $\mathrm{p}$ value $=0,654$ $>0,05$. Maka diketahui Ho ditolaksehingga tidak terdapat hubungan antara umur dengan kinerja perawat rumah sakitProvinsi Bangka Belitung Tahun 2017.

Pada hasil tabulasi silang jenis kelamin dengan kinerja perawat rumah sakit Provinsi Bangka Belitung Tahun 2017 diperoleh bahwa dari 194 orang, yang memiliki jenis kelamin perempuan sebanyak 73 orang $(79,3 \%)$ yang memiliki kinerja baik, sebanyak 75 orang $(71,4 \%)$ yang memiliki kinerja kurang. Pada Jenis Kelamin Laki-laki sebanyak 19 orang $(20,7 \%)$ yang memiliki kinerja baik, sebanyak 30 orang $(28,6)$ yang memiliki kinerja kurang. Berdasarkan uji Chi-Square menghasilkan p value $=0,264$ > 0,05 . Maka diketahui Ho ditolak sehingga tidak terdapat hubungan antara jenis kelamin dengan kinerja perawat rumah sakit Provinsi BangkaBelitung Tahun 2017.

Pada hasil tabulasi silang Pendidikan dengan kinerja perawat rumah sakit Provinsi Bangka Belitung Tahun 2017 diperoleh bahwa dari 194 orang (100\%), yang memiliki pendidikan D4/S1/S2 sebanyak 22 orang $(23,9 \%)$ yang memiliki kinerja baik, sebanyak 26 orang $(24,8 \%)$ yang memiliki kinerja kurang. Pada Pendidikan D3 sebanyak 70 orang $(76,1 \%)$ yang memiliki kinerja baik, sebanyak 79 orang $(79,4 \%)$ yang memiliki kinerja kurang. Berdasarkan uji Chi-Square menghasilkan $\mathrm{p}$ value $=1,000$ $>0,05$. Maka diketahui Ho ditolaksehingga tidak terdapat hubungan antara pendidikan dengan kinerja perawat rumahsakit Provinsi Bangka Belitung Tahun 2017.

Pada hasil tabulasi silang status perkawinan dengan kinerja perawat rumah sakit Provinsi Bangka Belitung Tahun 2017 diperoleh bahwa dari 194 orang, yang memiliki status sudah kawin sebanyak 67 orang $(72,8 \%)$ yang memiliki kinerja baik, sebanyak 74 orang $(70,5 \%)$ yang memiliki kinerja kurang. Pada status belum kawin sebanyak 25 orang $(27,2 \%)$ yang memiliki kinerja baik, sebanyak 31 orang $(29,5 \%)$ yang memiliki kinerja kurang. Berdasarkan uji Chi-Square menghasilkan $\mathrm{p}$ value $=0,838$ $>0,05$. Maka diketahui Ho ditolaksehingga tidak terdapat hubungan antara status perkawinan dengan kinerja perawat rumah sakit Provinsi Bangka Belitung Tahun 2017.

Tabel 2. Tabulasi Silang Karakteristik Individu dengan Kinerja Perawat Rumah Sakit Provinsi Bangka Belitung Tahun 2017

\begin{tabular}{|c|c|c|c|c|c|c|c|c|}
\hline \multirow{3}{*}{ Variabel } & \multicolumn{6}{|c|}{ KINERJA } & \multirow[t]{3}{*}{ Risk } & \multirow[t]{3}{*}{$p$ value } \\
\hline & \multicolumn{2}{|l|}{ Baik } & \multicolumn{2}{|l|}{ Kurang } & \multicolumn{2}{|l|}{ Total } & & \\
\hline & $f$ & $\%$ & $f$ & $\%$ & $f$ & $\%$ & & \\
\hline \multicolumn{9}{|l|}{ Umur } \\
\hline$\geq 30$ tahun & 42 & $40,0 \%$ & 33 & $35,9 \%$ & 75 & $38,1 \%$ & 0,839 & 0,654 \\
\hline$\leq 30$ tahun & 63 & $60,0 \%$ & 59 & $64,1 \%$ & 122 & $61,9 \%$ & $(0,471-1,495)$ & \\
\hline \multicolumn{9}{|c|}{ Jenis Kelamin } \\
\hline Perempuan & 73 & $79,3 \%$ & 75 & $71,4 \%$ & 148 & $75,1 \%$ & 0,651 & 0,264 \\
\hline
\end{tabular}




\begin{tabular}{|c|c|c|c|c|c|c|c|c|}
\hline Laki-laki & 19 & $20,7 \%$ & 30 & $28,6 \%$ & 49 & $24,9 \%$ & $(0,337-1,257)$ & \\
\hline \multicolumn{9}{|l|}{ Pendidikan } \\
\hline D4/S1/S2 & 22 & $23,9 \%$ & 26 & $24,8 \%$ & 48 & $24,4 \%$ & 0,955 & 1,000 \\
\hline D3 & 70 & $76,1 \%$ & 79 & $79,4 \%$ & 149 & $75,6 \%$ & $(0.497-1,834)$ & \\
\hline \multicolumn{9}{|l|}{ Status } \\
\hline \multicolumn{9}{|l|}{ Perkawinan } \\
\hline Sudah Kawin & 67 & $72,8 \%$ & 74 & $70,5 \%$ & 141 & $71,6 \%$ & 0,891 & 0,838 \\
\hline Belum Kawin & 25 & $27,2 \%$ & 31 & $29,5 \%$ & 56 & $28,4 \%$ & $(0,478-1,659)$ & \\
\hline \multicolumn{9}{|l|}{ Lama Kerja } \\
\hline >10 Tahun & 71 & $77,2 \%$ & 84 & $80 \%$ & 155 & $78,7 \%$ & 0,845 & 0,728 \\
\hline$<10$ Tahun & 21 & $22,8 \%$ & 21 & $20 \%$ & 42 & $21,3 \%$ & $(0,427-1,672)$ & \\
\hline
\end{tabular}

Pada hasil tabulasi silang lama kerja dengan kinerja perawat rumah sakit Provinsi Bangka Belitung Tahun 2017 diperoleh bahwa dari 194 orang, yang memiliki lama kerja lebih dari 10 tahun sebanyak 71 orang $(77,2 \%)$ yang memiliki kinerja baik, sebanyak 84 orang (80\%) yang memiliki kinerja kurang. Pada lama kerja kurang dari 10 tahun sebanyak 21 orang $(22,8 \%)$ yang memiliki kinerja baik, sebanyak 21 orang $(20 \%)$ yang memiliki kinerja kurang. Berdasarkan uji Chi-Square menghasilkan $\mathrm{p}$ value $=0,728>0,05$. Maka diketahui Ho ditolak sehingga tidak terdapat hubungan antara lama kerja dengan kinerja perawat rumah sakit Provinsi Bangka Belitung Tahun 2017.

Tabel 3. Tabulasi Silang Antara Motivasi Dengan Kinerja Perawat Rumah Sakit Provinsi Bangka Belitung Tahun 2017

\begin{tabular}{|c|c|c|c|c|c|c|c|c|}
\hline \multirow{3}{*}{ Motivasi kerja } & \multicolumn{6}{|c|}{ KINERJA } & \multirow{3}{*}{ Risk } & \multirow{3}{*}{$p$ value } \\
\hline & \multicolumn{2}{|c|}{ Baik } & \multicolumn{2}{|c|}{ Kurang } & \multicolumn{2}{|c|}{ Total } & & \\
\hline & $f$ & $\%$ & $f$ & $\%$ & $f$ & $\%$ & & \\
\hline Baik & 28 & $26.7 \%$ & 40 & $43.5 \%$ & 68 & $34.5 \%$ & 2. 115 & 0,020 \\
\hline Kurang & 77 & $73.3 \%$ & 52 & $56.5 \%$ & 129 & $65.5 \%$ & $(1,164-3,845)$ & \\
\hline
\end{tabular}

Sumber: Data Diolah, 2020

Pada hasil tabulasi silang motivasi dengan kinerja perawat rumah sakit Provinsi Bangka Belitung Tahun 2017 diperoleh bahwa dari 194 orang, yang memiliki motivasi baik sebanyak 28 orang $(28,7 \%)$ yang memiliki kinerja baik, sebanyak 40 orang $(43,5 \%)$ yang memiliki kinerja kurang. Pada motivasi kurang sebanyak 77 orang $(73,3 \%)$ yang memiliki kinerja baik, sebanyak 52 orang $(56,5 \%)$ yang memiliki kinerja kurang. Berdasarkan uji Chi-Square menghasilkan p value $=0,20<0,05$. Maka diketahui terdapat hubungan antara motivasi dengan kinerja perawat rumah sakit Provinsi Bangka Belitung Tahun 2017. 


\section{PEMBAHASAN}

1. Analisis univariat

Kinerja perawat dalam penelitian ini dilihat berdasarkan tingkat inisiatif serta kedisiplinan waktu. Menurut Suwondo dan Sutanto (2015), penilaian kinerja diukur dengan cara tingkat inisiatif serta disiplin waktu dan kehadiran. Indikator kinerja menurut Sulistiyani (2003) termasuk di dalamnya yakni inisiatif serta ketepatan waktu. Inisiatif merupakan dorongan untuk menemukan masalah atau peluang dan mampu mengambil tindakan konkret untuk memecahkan masalah atau mengambil peluang tersebut. Sedangkan pada kedisiplinan waktu merupakan ketepatan kehadiran individu.

Pada hasil proporsi faktor motivasi yang meliputi faktor gaji, supervise, kondisi kerja, dan pengakuan menunjukan hasil yang baik. Maka tidak terlalu tinggi nya motivasi kerja perawat rumah sakit Provinsi Bangka Belitung dapat disebabkan oleh rasa tanggung jawab yang dimiliki oleh perawat sehingga setiap melakukan tindakan keperawatan dilakukan dengan penuh rasa rasa tanggung jawab, meskipun faktor gaji, supervisi, kondisi kerja, dan pengakuan yang kurang baik tidak mempengaruhi secara langsung kepada perawat rumah sakit Provinsi Bangka Belitung. Sedangkan responden yang memiliki motivasi sedang dengan kinerja yang baik $(73,3 \%)$ dapat disebabkan oleh lingkungan kerja yang nyaman serta dukungan rekan kerja yang baik (Kiramah,2017).

Pada penelitian yang dilakukan di RSUD Tugurejo bahwa motivasi kerja yang tinggi dapat dipengaruhi oleh adanya supervisi yang dilakukan sebulan sekali oleh kepala keperawatan memberikan dampak pada perawat untuk berusaha melakukan tindakan keperawatan yaitu mengikuti prosedur dan asuhan keperawatan ( Fitri, 2007). Hal ini juga sejalan dengan dengan penelitian saragih (2018), bahwa semakin tinggi pelaksanaan supervisioleh keala ruangan maka semakin baik kinerja perawat pelaksananya (Saragih,2018). Adapun tujuan pemberian penghargaan seperti halnya pengakuan tersebut untuk menarik jumlah dan kualitas karyawan yang dibutuhkan, mendorong lebih banyakprestasi, dan mempertahankannya (Panggabean, 2004).

Pada penelitian di RSUD Bangka Barat diketahui perawat memilikikondisi kerja yang baik, yaitu hubungan rekan kerja dan atasan yang baik, keterampilan yang mampu mengimbangi pekerjaan, serta fasilitas-fasilitas yang memadai dan tata ruang yang mendukung (Gita,2016).

Adapun beberapa pendapatmengenai faktor gaji yaitu sistem penggajian di bidang keperawatan didasarkan pada kepangkatan dan pembayaran atas pelayanan pasien (Mahardika,dkk, 2012). Semangat tinggidalam melakukan tugas didapatkan jika semakin tinggi dorongan motivasi perawatan. Berbeda dalam penelitianmaryenti pada RSI Ibnu Sina Pekanbaru motivasi perawat yakni dorongan dari dirinya sendiri dan adanya pantauan serta arahan komite (Maryenti,2020). Pada penelitian RSUD Liun Kendage Tahuna, terdapat perawat kinerja kurang serta permasalahan dengan menurunyakedisiplinan perawat dan angka ketidakhadiran meningkat yang berdampak pada pergantian shift perawat(Glady,2018).

DOI : https://doi.org/10.51544/imn.v4i2.1824 


\section{Analisisi Bivariat}

Kinerja perawat dalam penelitian ini dilihat berdasarkan tingkat inisiatif serta kedisiplinan waktu. Menurut Taylor (2013) dalam inisiatif dibutuhkan kemampuan adaptasi dengan lingkungan sekitar untuk lebih berkembang. perawat yang mempertimbangkan berbagai alternatif di luar SOP menerima respon tidak setuju yang tinggi, yang menunjukkan bahwa perawat terikat dengan SOP . Jika melanggar SOP maka dapat melanggar etika kerja dan mendapatkan sanksi serta dapat berakibat fatal bagi keselamatan pasien (Wulan,2017). hal yang dapat dilakukan oleh pihak manajerial adalah dengan mengadakan training. Hal ini bertujuan untuk menambah pengetahuan dan keterampilan SDM.

Simmamora (2004) berpendapat bahwa karyawan dengan masa kerja kurang dari 10 tahun merupakan karyawan pada tahap awal karirnya. Selama masa persiapan karir masa depan, karir awal karyawan tidak akan selalu berjalan mulus. Dalam proses terjun dalam karir tersebut, beberapa kemungkinan masalah dapat muncul. Simmamora (2004) juga mengemukakan bahwa karyawan yang dengan masa kerja lebih dari 20 tahun berada pada tahap akhir karirnya, yaitu bersiap memasuki usia pensiun, dan beberapa diantaranya sudah mulai lepas dari tugas-tugas yang membelit. Hasibuan (2003) berpendapat bahwa organisasi harus mempertimbangkan usia, karena usia mempengaruhi fisik, mental, kemampuan kerja dan rasa tanggung jawab seseorang. Riyaldi (2007) menemukan bahwa ada hubungan yang signifikan antara usia dan kinerja, dengan pengalaman kerja 15 tahun di atas 25 tahun. Hal ini menunjukkan bahwa semakin tua atau semakin dewasa perawat tersebut maka semakin tinggi pula kinerja perawatnya.Pada hasil analisis umur, diketahui terbesar pada perawat dengan rentang umur 20-35 tahun dengan kinerja yang kurang baik
(86,7\%). Hal ini menunjukkan bahwa semakin tua atau semakin dewasa perawat tersebut maka semakin tinggi pula kinerja perawatnya yang berhubungan dengan semakin bertanggung jawab dan berpengalaman perawat tersebut. Namun semakin tua perawat, maka akan terjadi penurunan keterampilan fisik.

Robbins (2006) menunjukkan tidak adanya perbedaan berarti pada pria dan wanita dalam hal keterampilan pemecahan masalah, keterampilan analitis, motivasi dan keterampilan sosial. Pada hasil analisis jenis kelamin, diketahui terbesar pada perawat perempuan dengan kinerja kurang baik $(71,4 \%)$. Hal ini dapat dikarenakan perawat perempuan memiliki prioritas lain seperti kehamilan.

Notoadmodjo (2003) mengemukakan bahwa dibandingkan dengan orang yang berpendidikan lebih rendah, orang yang berpendidikan lebih tinggi juga akan memiliki pengetahuan yang lebih tinggi, dan kematangan pengetahuan tersebut dapat ditingkatkan oleh orang yang berpendidikan sehingga dapat mengambil keputusan. Pada hasil analisis pendidikan, diketahui terbesar pada responden dengan pendidikan D3 yang memiliki kinerja kurang baik $(79,4 \%)$. hal ini dapat dikarenakan perawat dengan pendidikan lebih tinggi memiliki pengetahuan dan wawasan yang lebih luas dibandingkan perawat dengan pendidikan rendah.

Berdasarkan penelitian Purbadi dan Sofiana (2006) kinerja pada orang yang menikah akan meningkat karena memiliki pemikiran yang lebih bijak dan matang, hal itu sangat penting untuk pelaksanaan prinsip moral. Status perkawinan seseorang sangat mempengaruhi kualitas pekerjaan seseorang. Pada hasil analisis status perkawinan, diketahui terbesar pada responden sudah kawin dengan kinerja yang kurang baik $(70,5 \%)$. Namun banyak pendapat yang 
menyatakan bahwa kinerja pada orang yang memiliki pemikiran yang lebih matang dan bijak untuk pelaksanaan prinsip moral akan meningkat setelah menikah.

Siagian (2002) mengemukakan bahwa semakin lama seseorang bekerja dalam suatu organisasi maka semakin tinggi pula produktivitasnya, karena karyawan memiliki pengalaman dan keterampilan yang semakin tinggi. Pada hasil analisis lama kerja, terbesar pada responden yang bekerja lebih dari 10 tahun dengan kinerja yang kurang baik. Namun banyak pendapat yang menyatakan bahwa pengalaman kerja memberikan banyak pengetahuan profesional dan keterampilan kerja. Sedangkan, pengalaman kerja yang terbatas akan menurunkan pengetahuan dan keterampilan profesional. Menurut Nursalam (2009), perawat yang memiliki masa kerja yang banyak maka pengalaman perawat dalam memberikan asuhan sesuai dengan standar yang berlaku atau prosedur yang ditetapkan.

Pada penelitian ini, motivasi kerja perawat rumah sakit di Provinsi Bangka Belitung, dilihat dari faktor gaji, kondisi kerja, supervisi, dan pengakuan. Sesuai dengan hasil uji chi-square didapatkan nilai $\mathrm{p}$ $=0,020$ hal ini berarti $\mathrm{p}$ lebih kecil dari $\alpha$ $(0,05)$ dengan demikian Ho ditolak atau terdapat hubungan antara motivasi dengan kinerja perawat rumah sakit Provinsi Bangka Belitung. Sedangkan pada variabel karakteristik individu tidak terdapat hubungan antara motivasi dengan kinerja perawat rumah sakit Provinsi Bangka Belitung. Penelitian - penelitian sebelumnya menyebutkan bahwa adanya hubunganantara motivasi dengan kinerja perawat. Diketahui pada hubungan motivasi dengan kinerja perawat rumah sakit Provinsi Bangka Belitung memiliki OR 2.115 yang artinya jika motivasi perawat baik maka akan memiliki peluang 2.115 kali berkinerja baik, dibandingkan perawat dengan motivasi yang kurang baik.

Penelitian yang dilakukan oleh Nurhaeni (2003) terhadap kinerja perawat di RS Jiwa Makassar menunjukkan bahwa terdapat hubungan yang signifikan antara motivasi dan kinerja,

Berdasarkan penelitian Nurhaeni(2003) terhadap kinerja perawat di RS Jiwa Makassar menunjukkan bahwa terdapat hubungan yang signifikan antara motivasi dan kinerja

Hal ini juga menunjukkan adanya kemungkinan terdapat faktor motivasi lainnya yang tidak terdapat pada penelitian ini yang dapat mempengaruhi perawat rumah sakit Provinsi Bangka Belitung.

\section{SIMPULAN}

Penelitian mengenai hubungan motivasi dengan kinerja perawat rumah sakit Provinsi Bangka Belitung diketahui bahwa kinerja perawat di rumah sakit Provinsi Bangka Belitung memiliki kinerja yang baik $(53,3 \%)$. Pada karakteristik individu , $(61,9 \%)$ responden berumur $\leq 30$ Tahun, $(79,3 \%)$ responden merupakan perempuan, $(76,1 \%)$ memiliki pendidikan D3, $(72,8 \%)$ responden sudah menikah, serta $(77,2 \%)$ responden telah bekerja selama lebih dari 10 Tahun. Motivasi kerja yang dimiliki perawat di rumah sakit Provinsi Bangka Belitung Sebagian besar responden yaitu 137 dari 197 orang berada dalam kategori motivasikurang $(69,5 \%)$. Hasil penelitian menunjukkan bahwa tidak terdapathubungan antara karakteristik individu dengan kinerja perawat rumah sakit Provinsi Bangka Belitung, sedangkan terdapat hubungan antara motivasi denga kinerjaperawat rumah sakit di Provinsi Bangka Belitung. Hal ini menunjukkan bahwa semakin baik motivasi yang dimiliki perawat, maka semakin pula kinerja yangdihasilkan perawat rumah sakit Provinsi Bangka Belitung tahun 2017.

DOI : https://doi.org/10.51544/imn.v4i2.1824 


\section{SARAN}

Penelitian ini merekomendasikan dalam meningkatkan kinerja perawat maka diharapkan pihak rumah sakit lebih memperhatikan aspek supervisi, misalnya dengan memberikan tanggapan yang baik saat konsultasi, diberikan pengarahan, dan petunjuk mengenai tugas perawat. Serta memperhatikan dari segi aspek insentif dan pengakuan. Untuk meningkatkan kinerja perawat berdasarkan aspek inisiatif, pihak rumah sakit dapat melakukan adanyatraining atau pelatihan untuk mengembangkan tingkat inisiatif perawat dalam bekerja.

\section{REFERENSI}

Asih, W. (2017). Peningkatan Kinerja Sumber Daya Manusia Melalui Inisiatif Dan Orientasi Pembelajaran Serta Kemampuan Penyesuaian. Ekobis, 18, 96-105.

Fajrianti, G. (2016). Hubungan Tugas Dan Lingkungan Dengan Stress Kerja Pada Perawat Rawat Inap. Penelitian Kesehatan Suara Forikes.

Fitri, N. (2017). Hubungan Antara Motivasi Kerja Dengan Kinerja Perawat Di Instalasi Rawat Inap Rumah Sakit Umum Daerah (Rsud) Tugurejo Semarang.

Gibson, J. L., Ivaneevich, J.M., and Dannelly, J. H. (1996). Perilaku Organisasi, Struktur dan Proses, Terjemahan. In Jilid I Edisi Ke-8. Erlangga.

Handoko, T. H. (1995). Manajemen Personalita Dan Sumber Daya Manusia (2nd ed.). BFPE.

Hasibuan, M. (2003). Manajemen Sumber Daya. BUmi Aksara.

Maryenti, F. (2020). Motivasi Dan Sikap Perawat Ruangan Terhadap
Kepatuhan Hand Hygiene Di RSI Ibnu Sina Pekan Baru. Mutiara Ners, $3(1), 1-7$.

Notoatmodjo, S. (2003). Pengembangan Sumber Daya Manusia. PT Rineka Cipta.

Nursalam. (2002). Manajemen Keperawatan (Aplikasi Dalam Keperawatan Praktek Profesional) (1st ed.). Salemba Medika.

Pangabean, M. (2004). Manajemen Sumber Daya Manusia. Penerbit Ghalia Indonesia.

Rivai, V. (2009). Manajemen Sumber Daya Manusia Untuk Perusahaan: Dari Teori Ke Praktik (2nd ed.). Rajawali Press.

Riyaldi, S. (2007). Hubungan Motivasi Kerja Dan Karakteristik Individu Dengan Kinerja Perawat Di RS Dr.H. Moh. Anwar Sumenep Madura.

Robbin, S. (2006). Perilaku Organisasi(10th ed.). PT Indeks Kelompok Gramedia.

Salawangi, G. E. (2018). Hubungan Motivasi Kerja Dengan Kinerja Perawat Di Instalasi. Kesmas, 7(5).

Saragih, M. (2018). Hubungan Pelaksanaan Supervisi Kepala Ruangan Dengan Kinerja Perawat Pelaksana Dalam Pendokumentasian Askep. Mutiara Ners, 1(1), 65-72.

Siagian, S. P. (2002). Kiat Meningkatkan Produktivitas Kerja. Asdi Mahasatya.

Sutanto, S. D. I. (2015). Hubungan lingkungan kerja, disiplin kerja, dan kinerja karyawan. Manajemen Dan Kewirausahaan, 17, 135-144.

Taylor, P. (2013). The Effect OfEntrepreneurial Orientation On The Internationalization Of Smes. Developing Countries. Academic, 7, 1927-1937.

DOI : https://doi.org/10.51544/imn.v4i2.1824 
Wati, K. (2017). Pengaruh Motivasi Kerja Terhadap Kinerja Perawat Pelaksana Di Ruang Rawat Inap Rumah Sakit Umum Daerah Alimuddin Umar Kabupaten Lampung Barat Tahun 2017. Kesehatan Holistik, 11, 209215.

Willis-Shattuck, M., Bidwell, P., Thomas, S. et a. (2008). Motivation and retention of health workers in developing countries: a systematic review. BMC Health Serv Res 8, 247.

DOI : https://doi.org/10.51544/imn.v4i2.1824

(C) 2021 Jurnal Mutiara Ners. This is an open accessarticleunder the CC BY-SA license Website : http://e-journal.sari-mutiara.ac.id/index.php/NERS/index 